\title{
New-Onset Diabetes after Renal Transplantation (NODAT): Risks \& Risk Factors
}

\author{
Debmalya Sanyal $^{1 *}$ and Kingshuk Bhattacharjee ${ }^{2}$ \\ ${ }^{1}$ Department of Endocrinology, KPC Medical College \& Hospital, India \\ ${ }^{2} J J T$ University, India
}

Submission: March 06, 2019; Published: April 17, 2019

*Corresponding author: Debmalya Sanyal, Professor, Department of Endocrinology, KPC Medical College \& Hospital, 700 053, 36 Block H New Alipore Kolkata, Jadavpur, West Bengal, India

Keywords: Renal transplantation; End-stage renal disease; Diabetes; Opportunistic infections; Renal allograft rejection; Transplant failure; Cardiovascular disease; Immunosuppression; Human leukocyte antigen; Donor sex; Magnesium levels

Abbrevations: RT: Renal Transplantation; NODAT: New-Onset Diabetes After Renal Transplantation; PTDM: Post-Transplant Diabetes Mellitus; DM: Diabetes Mellitus

\section{Mini Review}

Renal transplantation (RT) is the last resort for patients with end-stage renal disease and is the only way out to prolong the life expectancy of such patients with an improvement in the quality of life [1]. However, the anticipated benefits of RT have to be weighed against the potential risks viz. risk of developing new onset diabetes, opportunistic infections, renal allograft rejection and transplant failure [2]. New-onset diabetes after renal transplantation (NODAT) is a serious metabolic complication which not only heightens the mortality rate due to allograft rejection but also leads to increased cardiovascular disease [3]. NODAT is very much distinct from post-transplant diabetes mellitus (PTDM) where we exclude all the patients with a previous diagnosis of diabetes mellitus (DM) or unknown status of DM. The prevalence of NODAT is variable and is reported between $2 \%$ to $50 \%$, probably owing to inconsistent definitions used for diagnosing NODAT [4].

The higher prevalence of NODAT as reported from multiple studies of Indian sub-continent reflects the greater susceptibility of South Asian population to develop NODAT as compared to the Caucasians [5]. Thus, it would be prudent to identify this high-risk ethnic groups and follow-up them closely to shift them towards a favorable prognosis. A number of the modifiable as well as non-modifiable vis-à-vis traditional and novel risk factors have been identified for the development of NODAT. Many of these risk factors are general to diabetes population whereas some are unique to the transplant population [4].

The general risk factors includes increased age, high body mass index greater than $30 \mathrm{~kg} / \mathrm{m} 2$, African-American and Hispan ic ethnicity whereas the transplant specific risk factors includes usage of specific agents for immunosuppression, mismatch of human leukocyte antigen, donor sex and type of underlying renal disease [6] impaired glucose tolerance prior to transplant [7], and hyperglycaemia in the immediate perioperative period $[1,8,9]$. A recent prospective study from a tertiary care centre in Eastern India have additionally found magnesium levels, HbA1c level (pre as well as post-operative), ABO compatibility, insulin resistance (measured by HOMA-IR), insulin sensitivity (measured by HOMA-S) and decreased beta cell function \& c-peptide levels as significant predictors of NODAT. It is high time to translate this information and develop a risk-based scoring system to identify patients who are at risk of developing NODAT and monitor them closely for preventing untoward complications.

\section{References}

1. Chakkera HA, Knowler WC, Devarapalli Y, Weil EJ, Heilman RL, et al. (2010) Relationship between inpatient hyperglycemia andinsulin treatment after kidney transplantation and future new onset diabetes mellitus. Clin J Am Soc Nephrol 5(9): 1669-1675.

2. Memon SS, Tandon N, Mahajan S, Bansal VK, Krishna A, et al. (2017) The prevalence of new onset diabetes mellitus after renal transplantation in patients with immediate posttransplant hyperglycemia in a tertiary care centre. Indian J Endocr Metab 21(6): 871-875.

3. Wilkinson A, Davidson J, Dotta F, Home PD, Keown P, et al. (2005) Guidelines for the treatment and management of new-onset diabetes after transplantation. Clin Transplant 19(3): 291-298.

4. Montori VM, Basu A, Erwin PJ, Velosa JA, Gabriel SE, et al. (2002) Post transplantation diabetes: A systematic review of the literature. Diabetes Care 25(3): 583-592. 


\section{Current Research in Diabetes \& Obesity Journal}

5. Patel DD, Modi KP, Patel AK, Chaudhary V (2015) New onset of diabetes mellitus in Indian renal transplant recipient - A retrospective study. Int J Pharm Sci 7: 228-232.

6. Gaston RS, Basadonna G, Cosio FG, Davis CL, Kasiske BL, et al. (2004) Transplantation in the diabetic patient with advanced chronic kidney disease: A task force report. Am J Kidney Dis 44(3): 529-542.

7. Caillard S, Eprinchard L, Perrin P, Braun L, Heibel F, et al. (2011) Incidence and risk factors of glucose metabolism disorders in kidney transplant recipients: Role of systematic screening by oral glucose tolerance test. Transplantation 91(7): 757-764.
8. Sulanc E, Lane JT, Puumala SE, Groggel GC, Wrenshall LE, et al. (2005) New-onset diabetes after kidney transplantation: An application of 2003 International Guidelines. Transplantation 80(7): 945-952.

9. Kumar S, Sanyal D, Das P, Bhattacharjee K, Rungta R (2018) An observational prospective study to evaluate the preoperative risk factors of new-onset diabetes mellitus after renal transplantation in a tertiary care centre in eastern India. Indian J Endocr Metab 22(5): 610-615.

\section{Your next submission with Juniper Publishers will reach you the below assets}

- Quality Editorial service

- Swift Peer Review

- Reprints availability

- E-prints Service

- Manuscript Podcast for convenient understanding

- Global attainment for your research

- Manuscript accessibility in different formats

(Pdf, E-pub, Full Text, Audio)

- Unceasing customer service

Track the below URL for one-step submission https://juniperpublishers.com/online-submission.php 